\title{
Creating New Norms on Climate Change, Natural Disasters and Displacement: INTERNATIONAL DEVELOPMENTS 2010-2013
}

\author{
JANE MCADAM
}

\begin{abstract}
This article provides an account of attempts at the international level to develop a normative framework relating to climate change and migration from late 2010 to mid2013. It traces the "catalytic effect" of paragraph 14(f) of the Cancun Adaptation Framework (adopted in December 2010), through to the concerted, but ultimately unsuccessful effort of the United Nations High Commissioner for Refugees (UNHCR) in 2011 to get states to agree to the formulation of a "global guiding framework" on displacement relating to climate change and natural disasters. Finally, the article discusses the creation of the state-led Nansen Initiative in late 2012-a tentative "first step" towards international policy-making in this field-and the outcomes of its first sub-regional consultation in the Pacific in May 2013.
\end{abstract}

\section{Résumé}

Cet article rend compte des tentatives, au niveau international, de développer un cadre normatif dans le domaine des changements climatiques et de la migration, qui ont eu lieu entre la fin de 2010 et le milieu de 2013. Il retrace l'effet catalyseur du paragaphe $14(f) d u$ Cancún Adaptation Framework (adopté en décembre 2010) par le biais des efforts concertés du Haut Commissariat des Nations Unies pour les réfugiés, mais qui n’on ultimement pas réussi à amener les états à s'entendre sur la formulation d'un cadre de travail global en matière de déplacements dus aux changements climatiques et aux désastres environnementaux. Cet article discute enfin de la création de l'Initiative
Nansen vers la fin de 2012 - un essai de première étape vers l'établissement de politiques internationales dans le domaine - et des résultats de sa première consultation régionale dans le Pacifique en mai 2013.

\section{Introduction}

Over the past six or so years, a wealth of research has been published on the relationship between climate change and displacement. In part catalyzed by the publication of the Intergovernmental Panel on Climate Change's fourth assessment report in $2007,{ }^{1}$ scholars have sought to gather and refine empirical data about the impacts of climate change on human movement in particular regions and sub-regions of the world and to understand the role that climate change plays in driving such movement. While it is impossible to universalize the research findings, there is now a consensus on the following issues. First, climate change affects migration but cannot be isolated as the sole cause of movement. Rather, it interacts with and overlays other economic, social, and political drivers (or stressors) that themselves affect migration. It is a multi-causal phenomenon. Second, and closely linked to the previous point, climate change-related movement migration is a part of global migration dynamics generally, rather than a discrete, independent category, and it needs to be understood within a wider development context, not just a humanitarian one. ${ }^{2}$ Third, while adaptation can help to reduce vulnerability and enhance resilience, it is unlikely to stop the need for some migration. ${ }^{3}$ Indeed, migration can be a form of adaptation and a rational coping strategy, although the extent to which it is used to "flourish," rather than just to "survive," depends upon a person's resilience. ${ }^{4}$ Fourth, climate change-related displacement is 
likely to take different forms and will require a variety of responses at the local, national, regional, and international levels. ${ }^{5}$ Comprehensive approaches are needed across government departments and international agencies. For instance, migration management should be linked with other policy objectives, including climate change adaptation, disaster risk reduction, humanitarian responses, and sustainable development. Fifth, policies must be proactive, not just remedial, and there must be sufficient budgetary support for long-term planning. Finally, affected populations must be informed, consulted, and actively involved in decision-making and policy implementation through participatory processes.

The past three years have witnessed the most concerted attempts so far by the international community to develop new normative frameworks on climate change and human movement, albeit with mixed success. What has become manifestly clear is that states want to retain control over these developments, both in terms of how the issue is represented and how responses are shaped. They are reluctant to assume formal obligations or to "delegate" responsibility to international organizations.

This article provides an account of attempts at the international level to develop a normative framework relating to climate change and migration from late 2010 to mid2013. It traces the "catalytic effect" of paragraph 14(f) of the Cancún Adaptation Framework (adopted in December 2010), whereby states parties to the United Nations Framework Convention on Climate Change (UNFCCC) ${ }^{6}$ recognized "climate change induced displacement, migration and planned relocation" as elements to be addressed within the framework of climate change adaptation. ${ }^{7}$ This acknowledgement by states of the impacts of climate change on human mobility had threefold significance: as a matter of record; as a reference point to agitate for further action; and as a basis for securing adaptation funding to develop strategies on migration and resettlement. Against this backdrop, the article then examines the concerted, but ultimately unsuccessful, effort of the United Nations High Commissioner for Refugees (UNHCR) throughout 2011 to get states to agree to the formulation of a "global guiding framework" on displacement relating to climate change and natural disasters. ${ }^{8}$ Finally, the article discusses the creation of the state-led Nansen Initiative in late 2012-a tentative "first step" towards international policy-making in this field-and the outcomes of its first sub-regional consultation in the Pacific in May 2013.

Much of the article's focus is the strategic role played by UNHCR in putting the issue of climate change and displacement onto the international agenda. Given states' reluctance to implement their existing obligations under the Refugee
Convention and other protection instruments, ${ }^{9}$ UNHCR recognized from the outset that it would face a considerable challenge in motivating states to agree to new legal duties in this area.

My sense, based on personal observations over the course of this period as well as the extensive documentary record, is that states were resistant to being "pushed" into action by an agency that did not have a clear mandate for climate change-related displacement and was perceived by some as mandate-hunting. In some respects, perhaps the "push" happened too quickly. Even at the time, UNHCR was internally conflicted about whether or not it should be attempting to become more heavily involved, ${ }^{10}$ and most of the legwork happened within the 12 months immediately preceding the ministerial meeting in December 2011 (which may have contributed to the view expressed by some states that there was insufficient research on which to progress deliberations). ${ }^{11}$ At the same time, UNHCR saw the anniversaries marked by that meeting (the 60th anniversary of the Refugee Convention and the 50th anniversary of the Convention on the Reduction of Statelessness ${ }^{12}$ ) as providing a once-in-a-decade opportunity to advocate for enhanced protection commitments by states, and the meeting complemented (and fed into) parallel discussions in other forums (e.g. International Organization for Migration [IOM], Rio +20 , the UNFCCC process, Human Rights Council, and the International Law Commission) on the links between climate change, natural disasters, and displacement.

\section{The Cancún Adaptation Framework ${ }^{13}$}

The primary mechanism for the coordination of humanitarian assistance between relevant international United Nations (UN) and non-UN agencies is the Inter-Agency Standing Committee (IASC). In June 2008, the IASC established a Task Force on Climate Change to raise awareness of and integrate climate change into various humanitarian agency programs and to encourage increased inter-agency analysis and cooperation. ${ }^{14}$ One of its key objectives was to "lead the preparation of high-quality analytical inputs to the United Nations Framework Convention on Climate Change (UNFCCC) process,"15 and as Task Forcemembers, both UNHCR and the IOM were instrumental in advocating for cross-border displacement to be addressed in this context. ${ }^{16}$ Through concerted engagement with the UNFCCC process, the IASC helped to build a dialogue between the climate negotiators and humanitarian community, and each sector was better able to understand the interests and needs of the other. ${ }^{17}$ Furthermore, joint submissions by the heads of key humanitarian agencies sent "a coordinated signal" to states parties about the relevance of migration and displacement 
to their policy concerns, and the willingness of specialized agencies to support them in their endeavours. ${ }^{18}$

In December 2010, the UN climate change conference (COP16) adopted the Cancún Adaptation Framework, which was the result of three years of negotiations on adaptation by states parties to the UNFCCC. In the Framework, states parties affirmed that adaptation must be given the same priority as mitigation, and that enhanced action and international cooperation on adaptation was urgently required to reduce vulnerability and build resilience. ${ }^{19}$ Paragraph 14 invited all states parties to enhance action on adaptation under the Framework by undertaking, inter alia, "[m]easures to enhance understanding, coordination and cooperation with regard to climate change induced displacement, migration and planned relocation, where appropriate at the national, regional and international levels." 20

That such a provision was included at all, and was framed in this way, was largely due to the interventions of the IASC and the support of a number of states and scholars. ${ }^{21}$ The provision has three important features. First, it deliberately avoids questions of causation and responsibility, which are inevitably fraught. ${ }^{22}$ Second, it frames movement broadly (not only as displacement) and acknowledges that migration and planned relocation can be forms of adaptation. Third, it recognizes the need for multipronged strategies at different levels of governance rather than a single, universal response.

Koko Warner, a key participant in the drafting process, suggests that a crucial factor in states' acceptance of the provision was because mobility was framed as a technical, rather than a political, issue, which was presented as a "legitimate part of a wider adaptation framework." 23 Ironically, had proposed references to "human rights" and "climate justice" been added here (as some delegates proposed), they would likely "have been a liability to the very inclusion of migration and displacement in the Copenhagen outcomes," 24 given political sensitivities.

From a legal perspective, the provision is very weak. It is couched within a non-binding "decision" of the states parties to the UNFCCC and imposes no formal obligations on them, instead simply "inviting" them to undertake measures that assist "understanding, coordination and cooperation" on climate change-related mobility. It requires states neither to implement migration programs nor to "protect" people displaced by climate change. Arguably, this is appropriate in this context: while the climate change regime provides a high-profile "hook" for consideration of the protection and assistance concerns arising from migration and displacement, it is not a suitable forum in which to examine the complexity of these issues in a structured or comprehensive way.
However, from an advocacy perspective, the provision has far greater significance. First, it evidences states' recognition of the impacts of climate change on human movement and the need for strategies to address this. Second, it provides an important reference point and a "catalytic role" 25 for future initiatives seeking to tease out precisely what such measures might look like. Indeed, it sets out "many sensible options for beginning to think about (and undertake activities to address) the issue." 26 Third, it anticipates that planning for displacement, migration, and/or relocation will become part of states' national adaptation plans ${ }^{27}$ and as such will be eligible for funding pursuant to the Green Climate Fund. ${ }^{28}$

Paragraph 14(f) of the Cancún Adaptation Framework was an important precursor to UNHCR's actions in 2011. It provided the impetus (and partial justification) for UNHCR's strategy in 2011 to secure states' agreement to develop a global guiding framework on protection in the context of climate change and displacement, beginning with the Bellagio expert meeting in February of that year. ${ }^{29}$ An advantage of the provision was that it presented a state-determined point of reference for institutional actors to leverage action on climate change and mobility, in UNHCR's case by demonstrating the need for a new normative framework by highlighting the gaps in the existing protection regime. ${ }^{30}$ Paragraph 14(f) was also invoked in the "Chairperson's Summary" of the Nansen Conference on Climate Change and Displacement in the 21st Century as "an important global affirmation of the need for measures related to migration, displacement and planned relocation" whose "implementation should be explored through appropriate fora," 31 and a stated reason for the creation of the Nansen Initiative in late 2012. ${ }^{32}$ The provision has thus been described "both as a matrix and a call for action." 33

\section{UNHCR's Lead Role: Getting Climate Change and Displacement onto the International Agenda (2007-2010)}

As noted above, UNHCR was one of the key institutional players in the IASC's engagement with UNFCCC process and the lead author of a number of important submissions outlining the relationship between climate change and displacement. ${ }^{34}$ It was inevitable that UNHCR would be drawn into the debate on climate change and mobility, not least because of the early (mis)framing of the issue as being about "climate refugees." Internally, the organization remains divided about the extent to which it should engage with the subject, and coordination of the area has been "passed around the agency like a 'hot potato." 35 Some states have voiced their disquiet with a perceived de facto shift in emphasis as 
UNHCR engaged more and more with disaster-related displacement and the High Commissioner continued to highlight the protection gaps for those displaced by the impacts of disasters and climate change. ${ }^{36}$

UNHCR's legal mandate does not extend to displacement on account of disasters or the impacts of climate change, ${ }^{37}$ and this remains the chief obstacle to its formal involvement. ${ }^{38}$ However, the strong personal conviction of the High Commissioner, António Guterres, has driven the institution's engagement with the issue. ${ }^{39}$ Describing climate change as "the defining challenge of our times," 40 since 2007 Guterres has called on states to address contemporary circumstances in which there are "more and more people forced to move because of extreme deprivation, environmental degradation and climate change." ${ }^{1}$ He has argued that UNHCR has a "duty to alert states to these problems and help find answers to the new challenges they represent" 42 - "[i]n line with [its] statutory responsibility for the progressive development of international law in areas of [its] concern" 43 - and in any case is the UN agency "with responsibilities and expertise in the area of forced displacement."44

In 2010, UNHCR's Background Paper to the High Commissioner's Dialogue on Protection Challenges-an annual forum involving states, non-governmental (NGOs) and intergovernmental organizations, and the research community-placed natural disasters and climate change on the agenda as new drivers of displacement. It noted that "conflict, extreme deprivation and climate change are tending to act more and more in combination; a trend that is likely to intensify." 45 For the first time, it also directed attention towards possible normative responses. Identifying "a lack of international guidance on meeting the protection needs of people forcibly displaced as a result of climate change, natural disasters and other circumstances that may fall outside the scope of the 1951 Convention," 46 the paper asked, "Is the current architecture of humanitarian action adequate or are new mandates, institutions, coalitions or partnerships required?"47 It suggested that "additional tools might be required to translate the needs of the displaced into tangible forms of protection." 48 A side event on climate change and displacement was also convened during the Dialogue and was well attended by state representatives and others, including the High Commissioner. ${ }^{49}$

In the lead-up to the 2011 commemoration of the 60th anniversary of the Refugee Convention and the 50th anniversary of the Convention on the Reduction of Statelessness, it was decided that UNHCR would use the opportunity to renew states' interest in normative developments. The end goal was to secure pledges by states at a ministerial meeting in December 2011 to address normative gaps, especially (but not solely) in the context of climate change and natural disasters. ${ }^{50}$ However, for UNHCR to secure sufficient support, a number of interim steps were required.

\section{Bellagio Expert Meeting on Climate Change and Displacement (February 2011)}

Having put the issue on the agenda at the 2010 Dialogue, UNHCR's next step was to organize a closed Expert Meeting on Climate Change and Displacement, held in Bellagio in early 2011. Arguably, one of its strategic purposes of the meeting was to equip UNHCR with a sound and contemporary expert evidence base to provide at least tacit endorsement of its end-of-year objective. UNHCR asked the experts to consider the following "key questions":

- Is the present legal and policy framework sufficient?

- If not, is there a need for additional instruments to protect those displaced as a result of climate-related events?

- What legal and institutional responses could be contemplated with respect to "sinking island" states? ${ }^{21}$

With the deliberations framed in this way, it was almost inevitable that the expert group would identify the need for further normative development, given the limitations of the existing legal and policy framework, which were already well known. Scholars were commissioned to write background papers highlighting the reach and limitations of existing international law in protecting those displaced by climate change impacts, and were asked to identify the elements that a guiding global framework might contain. ${ }^{52}$ Although the expert group could not reach consensus on all issues, there was sufficient agreement on the following:

There is a need to develop a global guiding framework or instrument to apply to situations of external displacement other than those covered by the 1951 Convention, especially displacement resulting from sudden-onset disasters. States, together with UNHCR and other international organizations, are encouraged to explore this further. Consideration would need to be given to whether any such framework or instrument ought also to cover other contemporary forms of external displacement ...53

Given the magnitude of the issues involved, there is a need for a collaborative approach based on principles of international cooperation and burden - and responsibility-sharing. UNHCR's expertise on the protection dimensions of displacement makes it a particularly valuable actor. $^{54}$

This provided an imprimatur for the next stage of UNHCR's strategy: the Nansen Conference on Climate Change and Displacement in the 21st Century held in Oslo in June 2011. ${ }^{55}$ 


\section{The Nansen Conference and the Nansen Principles (June 2011)}

The Nansen Conference was convened by the Government of Norway, with the Center for International Climate and Environmental Research (Oslo) and the Norwegian Refugee Council, to explore responses to the "double predicament" of climate change and forced migration. ${ }^{56}$

Although UNHCR was not formally a co-sponsor of the event, it was a key player in its design. It was one of nine members of the conference's Advisory Board; it was singled out by the conference Chairperson, Margareta Wahlström (UN Special Representative of the Secretary-General for Disaster Risk Reduction for its "special support and involvement"; 57 and the High Commissioner was the only institutional head to speak in the opening plenary session. Furthermore, the name "Nansen" is inextricably bound with refugee protection: the famous Norwegian polar explorer and humanitarian was the first High Commissioner for Refugees for the League of Nations.

The conference was important in building momentum for international cooperation on climate change and displacement, especially because it brought together high-level actors from many UN and other international organizations, governments, NGOs, and the scientific and academic community from a wide range of disciplines. Its particular objective was to agree "a common set of broad principles," to be known as the "Nansen Principles," which would "underpin actions to prevent or manage displacement, and protect displaced people in the face of climate change." 58

As a government-led initiative, the Nansen Conference could more easily sidestep the politics and sensitivities around institutional mandates by including all relevant international organizations, without one in particular taking control or setting the agenda. It provided a relatively neutral space for other states to participate and a platform for a wide and diverse array of researchers and policymakers to present. At the same time, the process clearly fed into UNHCR's year-long plan to heighten states' awareness of the normative gaps, such that they would pledge at the December ministerial meeting to support UNHCR to develop a new global guiding framework on protection. Indeed, this was raised explicitly in the High Commissioner for Refugees' opening address. ${ }^{59}$

Norway had been one of the strongest state supporters of UNHCR's efforts to place climate change-related displacement on the international agenda. As early as 2007, it had encouraged UNHCR to "turn its attention to the issue of environmental degradation as a consequence of climate change, which was now at the top of the international agenda." 60 The Nansen Conference was framed squarely within the context of UNHCR's own initiatives to further international deliberations on the issue. It was described as "a timely and natural follow-up of the [Bellagio] expert conference on climate change and displacement organised by the Office of the United Nations High Commissioner for Refugees in February" 61 and an important precursor to UNHCR's ministerial meeting in December, ${ }^{62}$ and it was expected to feed into other policy processes, such as the upcoming UNFCCC negotiations and the Rio +20 conference on sustainable development. ${ }^{63}$ In his opening address to the Nansen Conference, the High Commissioner introduced UNHCR's vision for a "global guiding framework for situations of cross-border displacement resulting from climate change and natural disasters" 64 and said that states would be invited to make pledges in relation to gaps in the current protection regime at the ministerial meeting in December. ${ }^{65}$ In what could be interpreted as an appeal to states for an expanded mandate, he added that UNHCR could help to identify circumstances where such a framework would be activated and "develop procedures and standards of treatment for affected populations." 66

The most significant outcome of the conference was the Nansen Principles-a set of ten overarching principles designed to shape and inform further action on addressing the linkages between climate change and mobility, both normatively and practically. They reflected many of the "main messages" from UNHCR's Bellagio expert meeting, including the idea of a global guiding framework. ${ }^{67}$ The Principles emphasize the duties of states to their own populations and their need to ensure that adequate legislation, institutions, and resources are put in place, especially with respect to disaster risk reduction strategies. ${ }^{68}$ However, they also state that a "more coherent and consistent approach at the international level is needed to meet the protection needs of people displaced externally owing to sudden-onset disasters," and that "States, working in conjunction with UNHCR and other relevant stakeholders, could develop a guiding framework or instrument in this regard." 69 The Principles nderscore the complementary roles of local, national, regional, and international actors.

Differences of opinion as to how the Principles should be framed and what they should contain hinted at the immense difficulties that would be faced by UNHCR in its quest for a global guiding framework. ${ }^{70}$ Nevertheless, they reflect a policy consensus among key stakeholders and were proclaimed by the High Commissioner for Refugees as "a valuable contribution to the ministerial meeting that is planned for December."71

\section{ExCom's Standing Committee Meeting: June 2011}

According to those involved in the process within UNHCR, the agency's approach up to this point had been incremental, 
and deliberately so. The first stage of its strategy-the Bellagio expert meeting and the Nansen Conference-was relatively successful, and there was no obvious backlash from states-an accomplishment that should not be underestimated, given their general reticence to develop further protection norms. ${ }^{72}$

However, there was a discernible shift when states met at the Standing Committee of UNHCR's Executive Committee (ExCom) later in June 2011. There, UNHCR put forward a proposal by the IASC for UNHCR to become the lead agency for coordinating protection responses in situations of natural disaster. ${ }^{73}$ UNHCR was already the interagency cluster leader for international protection and for conflict-induced internal displacement, but there was no designated leader for natural disasters. The cluster leader for natural disasters was determined through a consultative process on a case-by-case basis, resulting in a lack of predictability in responses and delays in providing assistance. ${ }^{74}$ Following extensive consultations with the UN's Emergency Relief Coordinator from the Office for the Coordination of Humanitarian Affairs (OCHA) and the protection-mandated agencies, it was determined that UNHCR would be best placed to coordinate this response. ${ }^{75}$

In essence, the proposal sought to formalize a role that UNHCR had already assumed in seven natural disasters between 2004 and 2011, ${ }^{76}$ and at this point it was to be only a one-year pilot scheme. ${ }^{77}$ Thus, in operational terms at least, it did not signify a radical shift in practice. However, it was controversial, not least because it dealt with internally displaced persons ${ }^{78}$ - an already politically sensitive issueand generated concerns among states about UNHCR exceeding its mandate and operational capacity. ${ }^{79}$ While a number of states "recognized the need for strategies to deal with evolving forms of displacement, others urged prudence in this regard and suggested that the Office focus on ensuring more effective implementation of existing tools." ${ }^{0}$ One suspects that, for some delegations, granting UNHCR a formal operational role with respect to protection in natural disasters was a step too far: from there it was a slippery slope to UNHCR becoming the "forced migration" agency, rather than the "refugee" agency, and from providing humanitarian "assistance" in disasters, to acquiring a new legal "protection" mandate. Anecdotal evidence from some observers at the meeting suggests that the proposal sparked some of the most intense reactions by states ever witnessed in that forum. ${ }^{81}$ Although almost half of the delegates who spoke expressed support for the proposal in principle, many had reservations about the desirability of permitting UNHCR to assume additional responsibilities and activities. ${ }^{82}$ The majority of states emphasized that UNHCR should focus on its mandated responsibilities. Some remained unconvinced of the need for UNHCR to take on this extra role and called for further independent evaluation and information to show why it was required, as well as further discussion (including in the General Assembly). ${ }^{83}$ States' concerns centred on mandate implications, resources and capacity, exit strategies, and questions about state sovereignty (given that this would deal with internal displacement-still a very sensitive issue within the UNHCR context). ${ }^{84}$ As a result, " $t$ ] here was a clear call for postponement of any designation of responsibility as lead agency for protection in situations of natural disaster until outstanding questions were answered." 85

This did not bode well for the ministerial meeting in December. Even though the issue at the Standing Committee meeting was framed somewhat differently, it nonetheless suggested that if states were reluctant to grant additional operational responsibilities to UNHCR in the field of disasters and protection, it was unlikely that they would commit to developing further responsibilities for themselves.

\section{Statement to the UN Security Council (November 2011)}

Two weeks prior to the ministerial meeting, the High Commissioner for Refugees had the opportunity to address a UN Security Council briefing. In an impassioned statement, he explained that increasing numbers of people were "being forced to flee due to reasons that are not covered by the 1951 Refugee Convention" 86 and described climate change as "the defining challenge of our times ... which is adding to the scale and complexity of human displacement." 87 He concluded that "it would be appropriate for the international community to formulate and adopt a set of principles, specifically designed to reinforce the protection of and to find solutions for people who have been forced to leave their own country as a result of catastrophic environmental events, and who may not qualify for refugee status under international law." Urging all UN member states to support this initiative, he reminded them of the upcoming ministerial meeting "where we will examine these and other protection gaps affecting the world's forcibly displaced people." 88

\section{UNHCR'S Ministerial Meeting (December 2011)}

The ministerial meeting of December 2011 was a "landmark" event, attended by representatives of 155 states (including 72 ministers) to commemorate the 60th anniversary of the Refugee Convention and the 50th anniversary of the Convention on the Reduction of Statelessness. ${ }^{89}$ Given the small number of states that had indicated they would support UNHCR's call for normative expansion, there was 
a foreboding that the meeting held limited possibilities on this front.

In his opening address, the High Commissioner raised the theme of displacement on account of natural disasters and described climate change as "the key factor in accelerating all other drivers of forced displacement." ${ }^{90}$ He noted that while the majority of those affected would remain within their own countries, those who did cross an international border would not be considered refugees but also would not be "truly migrants," because they would not have moved voluntarily. Accordingly, they would find themselves "in a legal void." 91 The call to action was couched in the following terms: "So while the nature of forced displacement is rapidly evolving, the responses available to the international community have not kept pace. This has created a number of serious protection gaps, particularly in the context of mixed movements, large-scale complex emergencies and environmentally-related displacement. Whilst some national and regional initiatives have sought to address such gaps, there is no coherent international framework for protecting the rights of persons who are displaced across borders owing to forces other than persecution, serious human rights violations and ongoing conflict." 92

The meeting comprised plenary sessions and two roundtables, one of which was entitled "Protection Challenges and Opportunities: Where Will We Be in Ten Years?" It was in this context that the absence of a "coherent international normative framework for protecting the rights of persons who are displaced across borders owing to forces other than persecution, serious human rights violations and ongoing conflict" was raised for discussion. ${ }^{93}$ Under this topic, UNHCR posed the following questions for states to consider:

Could the existing normative framework be consolidated to more clearly identify where there are gaps? Reflecting upon existing good practice, could national responses and regional arrangements be further developed to fill these gaps? Would it be useful for States, UNHCR and other relevant actors to develop a global guiding framework or instrument to apply to situations of displacement across borders other than those covered by the 1951 Convention? If so, should this be limited to displacement relating to climate change and natural disasters, or could it be broader? Could temporary or interim protection arrangements be useful? If so, in which situations? ${ }^{94}$

UNHCR had hoped that this would encourage states to pledge to develop such a normative framework. However, only five states did. The pledge was made jointly by Norway and Switzerland, and endorsed by Costa Rica, ${ }^{95}$ Germany, and Mexico. It read, "A more coherent and consistent approach at the international level is needed to meet the protection needs of people displaced externally owing to sudden-onset disasters, including where climate change plays a role. We therefore pledge to cooperate with interested states, UNHCR and other relevant actors with the aim of obtaining a better understanding of such cross border movements at relevant regional and sub-regional levels, identifying best practices and developing consensus on how best to assist and protect the affected people." 96

Germany also stated that it was "ready to lend its support to initiatives that contribute to analyzing the impact of climate change and finding strategies to curb its effects, and help vulnerable populations build up a higher level of resilience." 97

Only four other states made reference to protection gaps relating to climate change and natural disasters. Latvia did not endorse the pledge but did note that in reflecting on the work needed to ensure the continuing relevance of the refugee protection regime, "serious consideration should be given to the consequences of global climate change." 98 Argentina pledged to strengthen the implementation of mechanisms that it had adopted to respond to "new situations that are not envisaged in the international instruments for refugee protection," including "special temporary resettlement" which applies, inter alia, to people who, "despite not requiring international protection, are temporarily unable to return to their countries of origin due to the prevailing humanitarian conditions or owing to the consequences generated by natural disasters or man-made environmental disasters." 99 China promised to share knowledge in the area of disaster relief, mitigation, and preparation, ${ }^{100}$ while Burundi said it would take urban refugees into account in strategies to reduce poverty and disaster risk. ${ }^{101}$ The InterParliamentary Union's support for “new approaches to deal with those displaced within or across national boundaries owing to environmental factors and natural disasters linked to climate change" was also noted. ${ }^{102}$

At the end of the meeting, a ministerial communiqué was issued. This did not refer to the topic of natural disasters or climate change, but instead noted only in general, and rather underwhelming, terms that “today's challenges in providing protection and achieving solutions continue to be serious, interconnected and complex. In this regard, we recognize the importance of enhancing international solidarity, strengthening action in accordance with the principles enshrined in applicable instruments and finding durable solutions. We will reinforce cooperation with each other and work with UNHCR and other relevant stakeholders, as appropriate, to deepen our understanding of evolving patterns of displacement and to agree upon ways to respond to the challenges we face in a changing global context."103 
As Walter Kälin has explained, this was not accidental but was a deliberate expression of "a lack of willingness by a majority of governments, whether from reasons of sovereignty, competing priorities or the lead role of UNHCR in the process," 104 to engage with displacement linked to disasters or climate change.

\section{The Nansen Initiative (October 2012)}

With such minimal support from states, UNHCR was in no position to advocate actively for a new "global guiding framework." It was apparent that states did not want to be "pushed" into action either by institutional actors or through an experts-based approach "introduced through the back door"105 - a criticism some states had made about the Guiding Principles on Internal Displacement. ${ }^{106}$ Thus, any new initiative would have to be driven from different quarters.

The Norwegian and Swiss governments considered that an intergovernmental process would best be able to take into account "the strong sensitivities of states towards the topic." 107 They detected in the ministerial communiqué "a certain, albeit very general, readiness to engage in a soft dialogue and to collect and share experience and practices in handling [climate change-related] displacement."108 Accordingly, in October 2012, they launched the Nansen Initiative on Disaster-Induced Cross-Border Displacement with the aim of building "a consensus on key principles and elements regarding the protection of persons displaced across borders in the context of natural disasters that sets the agenda for future action at domestic, regional and international levels." 109

The direct genesis of the Nansen Initiative was the joint pledge that Norway and Switzerland had made at the UNHCR ministerial meeting. This, in turn, had been stimulated by developments over the course of 2010-11: States' agreement at Cancún to enhance understanding and cooperation on climate change-induced migration, displacement, and relocation; and the Nansen Principles (especially Principles II and IX) that had emerged from the Nansen Conference and also been shaped by the findings of the Bellagio expert meeting. ${ }^{110}$

The Nansen Initiative, which will be operational from 2013 to 2015, is designed to promote a "bottom-up" approach to the issue. First, a series of sub-regional consultations will be conducted to gather more information about the varying challenges faced-as well as good practices adopted-in different parts of the world. ${ }^{111}$ They will focus on the various phases of displacement-preparedness prior to displacement, protection and assistance during displacement, and solutions following displacement. ${ }^{112}$ It is hoped that this process will enable national and sub-regional idiosyncrasies to be addressed and trust to be fostered between states. ${ }^{113}$

Second, through a global dialogue, the Nansen Initiative aims to develop a non-binding Protection Agenda based on three pillars: international cooperation and solidarity; standards for the treatment of affected people regarding admission, stay, and status; and operational responses, including funding mechanisms and responsibilities of international humanitarian and development actors. ${ }^{114}$ It is envisaged that the Protection Agenda will serve as "a framework for further normative, institutional and operational development at different levels." 115

While the Initiative's approach may be criticized as too tentative, it seems to be the only feasible strategy at this point in time. As the envoy, Walter Kälin, explained at the first Consultative Committee meeting, an absence of sufficient knowledge about "what happens on the ground" would make it difficult at this stage to draft a set of guiding principles adequately reflecting realities, and there is of course the practical obstacle as well, namely "the difficulty of getting governments on board with the idea of producing a normative framework right away." 116

Even though the Nansen Initiative is state-led, there is a strong emphasis on its being an "open, dynamic, and inclusive process" that will actively involve non-state stakeholders. ${ }^{117}$ Otherwise, there is a risk that it would "suffer from lack of relevance." 118 Co-chaired by Norway and Switzerland, it is overseen by a steering group that also includes Australia, Bangladesh, Costa Rica, Germany, Mexico, Kenya, and the Philippines. The composition of the steering group aims to ensure adequate and balanced representation from the global North and South. ${ }^{119}$ A consultative committee comprising representatives from relevant international organizations, NGOs, think tanks, and academics informs and supports the process. The envoy of the chairmanship is to represent the Initiative and provide strategic advice, while a small secretariat in Geneva provides logistical support. ${ }^{120}$

Of the international organizations involved, UNHCR has a special role: it is a member of the steering committee and was a "catalyst" in putting the issue higher on the international agenda. ${ }^{121}$ During the launch of the Initiative, one sensed a certain suspicion by states about UNHCR's role in the process, with both France and the United States separately seeking clarification of the precise nature of its involvement, ${ }^{122}$ and others calling for IOM to be closely engaged. ${ }^{123}$ At the launch, the envoy explained that IOM "would be an important partner in the process," 124 and subsequently affirmed that "UNHCR, IOM and the Norwegian Refugee Council will play active roles." 125

In terms of the Nansen Initiative's substantive work, it is significant that its focus is disaster-induced cross-border 
displacement. Earlier iterations of its mandate referred to natural disasters "particularly in the context of climate change," but the decision to remove such references was strategic. In part, this was to diffuse political sensitivities around the climate change-displacement nexus, and in part to circumvent the empirical and conceptual difficulties with causation, which could serve as a distraction to policy development if states were otherwise committed to finding pragmatic ways forward. ${ }^{126}$ It thus goes beyond paragraph 14(f) of the Cancún Adaptation Framework in that it considers not only climate change-related but geophysical disasters as well. ${ }^{127}$

Of course, from a "climate justice" perspective, it could be argued that the Initiative's focus on disasters, rather than climate change, misses an important opportunity to highlight the impact of climate change on human mobility and, in particular, to leverage climate change funding and assistance. However, as explored below, in reality this has not prevented the Initiative from examining climate changerelated mobility. From a pragmatic perspective, focusing on "disasters" rather than "climate change" was key to securing (some) states' cooperation and support, and thus facilitating the potential reach and influence of the Initiative. And, as was noted in the "Chairperson's Summary" of the Nansen Conference on Climate Change and Displacement, "From a protection perspective, there is no compelling reason to distinguish between displacement due to climate-related and other disasters." 128

The breadth of the Nansen Initiative's remit depends, though, on how the concept of "disaster" is understood. The Initiative adopts the definition of "disaster" used by the humanitarian community within the UN: "A serious disruption of the functioning of a community or a society involving widespread human, material, economic or environmental losses and impacts, which exceeds the ability of the affected community or society to cope using its own resources." 129 Importantly, rather than conceptualizing a "disaster" as an event, the emphasis is instead on its consequences - the coping capacity of those affected. This is particularly important, given the Initiative's focus on both "sudden-onset disasters" (defined as "hydro-meteorological hazards such as flooding, windstorms or mudslides, and geophysical hazards including earthquakes, tsunamis or volcano eruptions") and "slow-onset disasters" (defined as "environmental degradation processes such as droughts and desertification, increased salinization, rising sea levels or thawing of permafrost"). ${ }^{130}$ While the concept of a "slowonset disaster" seems counterintuitive if one thinks of a "disaster" as an "event" that happens (like a flood or landslide), it makes sense when a disaster denotes diminished coping capacity.
However, the concept note explains that slow-onset disasters come within the ambit of the Initiative only "in their end phase (i.e. when droughts or rising sea levels create life-threatening situations)," since this is when their effects "may be very similar to those of sudden-onset disasters." 131 It emphasizes that the relevant distinction "should not be the character of the disaster but rather whether it triggers displacement understood as forced movement of persons as opposed to voluntary migration." ${ }^{32}$ This sits uncomfortably with scenarios where migration is a rational and desirable form of adaptation, ${ }^{133}$ such as in some small island states. As Elizabeth Ferris has remarked, "[S]udden-onset disasters-cyclones, hurricanes, earthquakes ... are the 'easy' events to identify." 134 The greater challenge lies in responding to the impacts of slower processes, which potentially pose a more permanent risk to the sustainability of certain human settlements in the longer term. The concept note states only that the Nansen Initiative "should be open to look at the close relationship" between cross-border displacement and related issues such as "migration as adaptation." 135 Without sustained examination of the latter, it is inevitable that protection gaps will remain. Furthermore, it is crucial that the existence of the Initiative is not used as an excuse to delay policy development in these areas.

Of course, it remains to be seen precisely how states involved in the Initiative will conceptualize "displacement" and "disasters," especially once the sub-regional consultations have highlighted the challenges faced in specific contexts (including small island states). Could the idea of a "creeping disaster" 136 be one way of incorporating anticipatory movement as a protection response? As the Initiative has already acknowledged, the legal challenge will be to identify the "tipping point where the basically voluntary movement of persons turns into forced movement." Since, operationally, there may be considerable overlap between the two, "it [is] necessary to ensure that victims of forced displacement triggered by slow-onset disasters receive protection and assistance, too." 137

The outcomes of the first sub-regional consultation, held in the Cook Islands in May 2013, are reassuring on this front. The concept of "disasters" did not constrain deliberations or recommended actions for further action. Longerterm processes affecting mobility were a key part of the discussions, and many of the final recommendations related to long-term planning, including with respect to creating migration pathways, finding suitable land for resettlement, and ensuring that climate change adaptation and mitigation efforts continue. ${ }^{138}$

Further, the absence of "climate change" from the Nansen Initiative's mandate did not seem to hamper its work either. In fact, the Initiative's focus on disasters 
appears to have widened, rather than obscured, the kinds of deliberations that would have occurred had the focus been on climate change alone. For example, the Pacific consultation was entitled "Human Mobility, Natural Disasters and Climate Change in the Pacific," reflecting the specific challenges facing that region. As Prime Minister Henry Puna noted in his opening address, "Climate change is one of the most pressing concerns that we-as Small Islands Developing States-face in the Pacific."139 The consultation considered questions of loss and damage within the UNFCCC process, and some participants raised the possibility of international climate change adaptation funds being utilized for disaster risk management, preparation, and planned movement. Indeed, as noted above, the creation of the Nansen Initiative was itself a response to paragraph 14(f) of the Cancún Adaptation Framework, and its sub-regional consultations are structured around the three forms of mobility outlined there: displacement, migration, and planned relocation.

\section{Conclusion}

The creation of a new international treaty on climate change and displacement now seems even more unlikely than ever before. ${ }^{140}$ On the one hand, this is because of enhanced understanding within the international community about the conceptual difficulties involved in attributing displacement to the impacts of climate change alone. On the other hand, it stems from states' reluctance to assume new legal obligations in the protection context-in other words, a lack of political will. There has been strong pushback from states when questions of normative development or mandate extension have been proposed by UNHCR and others. States have made clear that they wish to control any initiatives on this front, and that they are prepared only to take tentative steps at this stage.

What might this say about the development of protection norms more generally? Even the adoption of soft law has become increasingly contentious in recent years. ExCom Conclusions, for example, have become increasingly difficult to negotiate ${ }^{141}$ and weaker in their normative content. Yet, while it is clear that even achieving soft law frameworks will take time, this is not necessarily a bad thing. Soft law can be important in creating a basis for dialogue between states and can enable them to experiment with new ideas without assuming formal commitments. ${ }^{142}$ In the context of climate change, disasters, and displacement, it is imperative that protection frameworks are attuned to the needs of those who will move, which means that they must be underpinned and informed by high-quality research. The collaborative approach advocated by the Nansen Initiative holds considerable promise for sustained dialogue between governments, organizations, and researchers, and-fundamentally-each of these constituencies must also ensure that the voices of affected communities are heard if a new protection agenda is to be truly responsive to needs. Ultimately, the goodwill of all stakeholders to listen, share knowledge, and build trust will enable the international community to take its first steps towards building a normative framework on protection in the context of disaster-induced cross-border displacement.

\section{Acknowledgement}

Thank you to Agnès Hurwitz (formerly of UNHCR) and Abdul Saboor Atrafi (from the Nansen Initiative Secretariat) for their comments, and Fiona Chong for research assistance.

\section{Notes}

1. Intergovernmental Panel on Climate Change (IPCC), Climate Change 2007: Synthesis Report; Summary for Policymakers (Cambridge: Cambridge University Press, 2007). See also the reports by each working group: $<$ http://www. ipcc.ch/publications_and_data/publications_and_data_ reports.shtml\#1>.

2. Asian Development Bank, Addressing Climate Change and Migration in Asia and the Pacific: Final Report (Manila: Asian Development Bank, 2012) at viii.

3. Government Office for Science, Foresight: Migration and Global Environmental Change; Future Challenges and Opportunities (London: Government Office for Science, 2011) at $9-10$.

4. Susan F. Martin, with Koko Warner, Tamer Afifi, Walter Kalin, Scott Leckie, Beth Ferris, \& David Wrathall, Changing Climates, Moving People: Framing Migration, Displacement and Planned Relocation (Bonn: United Nations University, 2013), <http://issuu.com/georgetownsfs/docs/ policy_brief_8_web> at 8 .

5. See e.g. The Nansen Initiative, Human Mobility, Natural Disasters and Climate Change in the Pacific, Report from the Nansen Initiative Pacific Regional Consultation (Rarotonga, Cook Islands: Nansen Initiative, 2013) at 6-8.

6. United Nations Framework Convention on Climate Change, 9 May 1992, 1771 UNTS 107, Can TS 1994/7 (entered into force 21 March 1993, ratification by Canada 4 December 1992).

7. The Cancun Agreements: Outcome of the Work of the Ad Hoc Working Group on Long-term Cooperative Action under the Convention, FCCC Dec 1/CP.16, UNFCCC, 16th Sess, UN Doc FCCC/CP/2010/7/Add.1 (15 March 2011) at para 14(f).

8. UNHCR, Intergovernmental Event at the Ministerial Level of Member States of the United Nations on the Occasion of the 60th Anniversary of the 1951 Convention relating to the Status of Refugees and the 50th Anniversary of the 1961 Convention on the Reduction of Statelessness (7-8 December 
2011), Background Note for the Roundtables, UN Doc HCR/ MINCOMMS/2011/08 (18 November 2011).

9. Convention relating to the Status of Refugees, 28 July 1951, 189 UNTS 137, Can TS 1969/6 (entered into force 22 April 1954, accession by Canada 2 September 1969), read in conjunction with the Protocol relating to the Status of Refugees, 31 January 1967, 606 UNTS 267, Can TS 1969/29 (entered into force 4 October 1967, accession by Canada 4 June 1969); see also Convention against Torture and Other Cruel, Inhuman or Degrading Treatment or Punishment, 10 December 1984, 1465 UNTS 85, Can TS 1987/36 (entered into force 26 June 1987, ratification by Canada 24 June 1987); International Covenant on Civil and Political Rights, 16 December 1966, 999 UNTS 171, Can TS 1976/47 (entered into force 23 March 1976, accession by Canada 19 May 1976).

10. Nina Hall, "Climate Change and Organizational Change in UNHCR" in Michelle Leighton, Xiaomeng Shen \& Koko Warner, eds, Climate Change and Migration: Rethinking Policies for Adaptation and Disaster Risk Reduction (Bonn: United Nations University, 2011), online: United Nations University <http://www.ehs.unu.edu/file/get/8468> at 111 explains that as at mid-2010, the planning was still in its formative stages. While there were suggestions that the meeting could examine how protection gaps might be filled, and that natural disasters might be one feature, nothing had been decided at that point in time.

11. In my view, some states have used the "research gap" argument as a pretext to stall developments in this area, especially since there is now a very large body of research available. I made comments to this effect at the first Consultative Committee meeting of the Nansen Initiative: The Nansen Initiative, Minutes of the Nansen Initiative Consultative Committee Meeting, Palais des Nations, Geneva, 2 October 2012, at 5.

12. Convention on the Reduction of Statelessness, 30 August 1961, 989 UNTS 175, Can TS 1978/32 (entered into force 13 December 1975, accession by Canada 17 July 1978).

13. For a comprehensive overview, see Koko Warner, "Climate Change Induced Displacement: Adaptation Policy in the Context of the UNFCCC Climate Negotiations," Legal and Protection Policy Research Series (UNHCR: Geneva, 2011), online: UNHCR <http://www.unhcr.org/4df9cc309. html>.

14. IASC Task Force on Climate Change, "Mid-Term Report for 2010" (9 July 2010), online: IASC $<$ http://www.humanitarianinfo.org/iasc/pageloader.aspx?page $=$ content - documents-default\&bodyID $=76 \&$ publish $>$ at 1 .

15. IASC, Addressing the Humanitarian Challenges of Climate Change: Regional and National Perspectives: Findings from the IASC Regional and National Consultations, May-June 2009 (Geneva: IASC, 2009) at 9.

16. Comments of Walter Kälin, Minutes of Meeting: Launch of the Nansen Initiative, Palais des Nations, Geneva, 2 October 2012, at 6 .
17. Warner, supra note 13 at 8 .

18. Ibid at 7. See e.g. IASC, "Climate Change, Migration and Displacement: Who Will Be Affected?” 31 October 2008, online: UNFCCC <http://unfccc.int/resource/docs/2008/ smsn/igo/022.pdf>; IASC, supra note 15; Koko Warner, "Workshop Report," Research Workshop on Migration and the Environment, 18 April 2008, online: Climate Change, Environment and Migration Alliance <http://www.ccema -portal.org/file/get/5774>; IASC Working Group on Migration/Displacement and Climate Change, "Displacement and Climate Change: Towards Defining Categories of Affected Persons," working paper first draft, 20 September 2008; Informal Taskforce on Climate Change of the IASC and the International Strategy for Disaster Reduction, "Disaster Risk Reduction Strategies and Risk Management Practices: Critical Elements for Adaptation to Climate Change," 11 November 2008, online: UNHCR $<$ http://www.unhcr.org/4a1e4f782.pdf >; Office of UNHCR, "Forced Displacement in the Context of Climate Change: Challenges for States under International Law" (20 May 2009), online: UNHCR <http://www.unhcr.org/4a1e4d8c2 .html>; UNHCR, "Climate Change and Statelessness: An Overview” (15 May 2009), online: UNFCCC <http:// unfccc.int/resource/docs/2009/smsn/igo/048.pdf >. Some of these are cited in Warner, supra note 13 at 7-8, fn 22.

19. The Cancun Agreements: Outcome of the Work of the Ad Hoc Working Group on Long-term Cooperative Action under the Convention, supra note 7 at paras 2(b), 11.

20. Ibid.

21. For an overview of the drafting history and framing of the issue, see Warner, supra note 13.

22. Note that in the earliest mentions of climate change and mobility in the assembly text at Poznan (COP14, December 2008), discussions were framed around the notion of the "climate refugee" (see also Summary of Views Expressed during the Second Session of the Ad Hoc Working Group on Long-term Cooperative Action under the Convention: Note by the Chair, UN Doc FCCC/AWGLCA/2008/11 (11 August 2008) at 9 (Bangladesh)). In June 2009, the head of the US delegation raised concerns about the use of this language in the text, and it was subsequently revised: referred to in Koko Warner, Migration and Global Environmental Change: Migration and Displacement in the Context of Adaptation to Climate Change: Developments in the UNFCCC Climate Negotiations and Potential for Future Action (London: Foresight, UK Government, 2011), online: UK Department for Business, Innovation \& Skills, <http:// www.bis.gov.uk/assets/foresight/docs/migration/policy -development/11-1269-pd23-migration-displacement -in-adaptation-climate-change.pdf $>$ at 8 . See earlier versions: Report of the Ad Hoc Working Group on Long-term Cooperative Action under the Convention on Its Seventh Session, Held in Bangkok from 28 September to 9 October 2009, and Barcelona from 2 to 6 November 2009, UN Doc FCCC/ AWGLCA/2009/14 (20 November 2009), online: UNFCCC 
<http://unfccc.int/resource/docs/2009/awglca7/eng/14 .pdf $>$ at 38, para 12(c) and at 56, para 13(b). On causation and state responsibility, see e.g. Roda Verheyen, Climate Change Damage and International Law: Prevention Duties and State Responsibility (Leiden: Martinus Nijhoff, 2005).

23. Warner, supra note 22 at 4.

24. Ibid at 9.

25. Warner, supra note 13 at 17. The fifth "Assessment Report" (2013) of the Intergovernmental Panel on Climate Change (IPCC) has a sub-chapter on climate change and mobility, and it is addressed in other chapters as a cross-cutting issue.

26. Ibid at 12 .

27. For a list of National Adaptation Programmes of Action where it is already referenced, see Jane McAdam, Climate Change, Forced Migration, and International Law (Oxford: Oxford University Press, 2012) at 271-80.

28. Ibid at 232; Walter Kälin, "From the Nansen Principles to the Nansen Initiative" (2012) 41 FMR at 48.

29. Kälin, supra note 28 at 49.

30. See UNHCR, supra note 8.

31. "Chairperson's Summary," in The Nansen Conference: Climate Change and Displacement in the 21st Century (Oslo, Norway, June 5-7, 2011) (Oslo: Norwegian Refugee Council, 2011), online: UNHCR <http://www.unhcr.org/4ea969729 .pdf $>$ at 19, para 10.

32. The Nansen Initiative, "Towards a Protection Agenda for Disaster-Induced Cross-Border Displacement” (leaflet circulated at the launch on 2 October 2012), online <http:// www.nanseninitiative.org/sites/default/files/Nansen $\% 20$ Initiative\%20Leaflet.pdf> at 1.

33. "Climate Change Adaptation and Disaster Risk Reduction: Key Messages from the Presentations," in The Nansen Conference: Climate Change and Displacement in the 21st Century, supra note 31 at 10.

34. See e.g. UNHCR, "Forced Displacement in the Context of Climate Change: Challenges for States under International Law," supra note 18; UNHCR, "Climate Change and Statelessness: An Overview," supra note 18.

35. Hall, supra note 10 at 110 ; see generally Hall, supra note 10 at $108-10$, referring to interviews with UNHCR staff. Criticisms include concerns about UNHCR "overreaching its mandate and operational capacity," as well as concerns that focusing on climate change as a driver of displacement might come at the expense of other pressing and widespread causes. See also Nina Hall, "Moving beyond Its Mandate? UNHCR and Climate Change Displacement" (2013) 4 J. of Int'l Orgs Studies 91.

36. See e.g. UNHCR Executive Committee, "Report of the 51st Meeting of the Standing Committee (21-23 June 2011)" (20 September 2011), UN Doc A/AC.96/1104 at 7-8, paras 32, 34; UNHCR Executive Committee, "Report of the 50th Meeting of the Standing Committee (1-3 March 2011)" (24 June 2011), UN Doc A/AC/96/1097 at 5, para 15; UNHCR Executive Committee, "Report of the 61st Session of the
Executive Committee of the High Commissioner's Programme (4-8 October 2010)" (12 October 2010), UN Doc A/AC.96/1095 at 16, para 7; UNHCR Executive Committee, "Report of the 44th Meeting of the Standing Committee (3-5 March 2009)" (30 June 2009), UN Doc A/ AC.96/1065 at 7, para 28; UNHCR Executive Committee, "Report of the 43rd Meeting of the Standing Committee (23-24 September 2008)" (8 October 2008), UN Doc A/ AC.96/106 at 8, para 37; UNHCR Executive Committee, "Summary Record of the 610th Meeting" (1 October 2007), UN Doc A/AC.96/SR.610, 14, para 62. See also António Guterres, "Opening Statement" (statement by UN High Commissioner for Refugees, delivered at the 58th Session of the Executive Committee of the High Commissioner's Programme, Geneva, 1 October 2007).

37. Unless they also fall within UNHCR's mandated areas of responsibility: see further McAdam, supra note 27 at 39-51.

38. Note, however, the UN Economic and Social Council's praise of UNHCR's activities in "the context of man-made disasters": Report of the United Nations High Commissioner for Refugees, ESC Res 2011(LXI), UNESCOR, 61st Sess, Supp No 1, UN Doc E/5889, (1976) at 2.

39. See further Hall, supra note 10; McAdam, supra note 27 at 225-29.

40. António Guterres, "Maintenance of International Peace and Security: New Challenges to International Peace and Security and Conflict Prevention" (statement by UN High Commissioner for Refugees, United Nations Security Council Briefing, New York, 23 November 2011), online: UNHCR <http://www.unhcr.org/4ee21edc9.html > at 3. He did note, however, that climate change is not an independent variable but rather interacts with and reinforces "other global imbalances": ibid.

41. Guterres, supra note 36.

42. Ibid. However, a Working Group on Solutions and Protection within the Executive Committee of the UNHCR reported as early as 1991 that there was "a need to provide international protection to persons outside the current international legal definition of refugee [where they were] forced to leave or prevented from returning to their homes because of human-made disasters, natural or ecological disasters": Michelle Schwartz, "International Legal Protection for Victims of Environmental Abuse" (1993) 18 Yale J. Int'l L. 355 at 379 .

43. José Riera, "Challenges relating to Climate Change Induced Displacement" (remarks by Senior Adviser to the Director of International Protection, UNHCR, "Millions of People without Protection: Climate Change Induced Displacement in Developing Countries" Conference, Berlin, 29 January 2013 at 6.

44. António Guterres (UN High Commissioner for Refugees), "Climate Change, Natural Disasters and Human Displacement: A UNHCR Perspective” (23 October 2008), online: UNHCR, <http://www.unhcr.org/4901e81a4.html> at 1. 
See also remarks of UNHCR staff in Hall, supra note 10 at 106, 111, who stated that the High Commissioner had signalled his intention in internal meetings to shift UNHCR from a "refugee" agency to a "forced migration" agency.

45. UNHCR, "Protection Gaps and Responses," background paper (30 November 2010), online: UNHCR <http://www .unhcr.org/4cebeeee9.html $>$ at 2 .

46. Ibid at 6.

47. Ibid at 4 .

48. Ibid.

49. UNHCR, "Side Event to High Commissioner's Dialogue on Protection Challenges 2010: Climate Change and Displacement" (8 December 2010), online: UNHCR <http://www .unhcr.org/4cff4c709.html>.

50. UNHCR, supra note 8 at 4.

51. UNHCR, "Climate Change and Displacement: Identifying Gaps and Responses" (22-26 February 2011), online: UNHCR <http://www.unhcr.org/cgi-bin/texis/vtx/home/ opendocPDFViewer.html?docid=4d1c92bb9\&query=bell agi $>$ at 2. It was unfortunate that the third of these questions effectively dropped off the agenda because it was seen as too specific to be dealt with in the time available.

52. Susin Park, "Climate Change and the Risk of Statelessness: The Situation of Low-Lying Island States," UNHCR Legal and Protection Policy Research Series (May 2011), online: UNHCR <http://www.unhcr.org/4df9cb0c9 .pdf>; Jane McAdam, "Climate Change Displacement and International Law: Complementary Protection Standards" (April 2011), UNHCR Legal and Protection Policy Research Series, online: UNHCR <http://www.unhcr .org/4dff16e99.html>; Warner, supra note 13; Roger Zetter, "Protecting Environmentally Displaced People: Developing the Capacity of Legal and Normative Frameworks" (February 2011), online: Oxford Refugee Studies Centre <http:// www.rsc.ox.ac.uk/search?SearchableText=Protecting + Environmentally+Displaced+People $>$.

53. UNHCR, "Summary of Deliberations on Climate Change and Displacement" (22-25 February 2011), online: UNHCR < http://www.unhcr.org/4da2b5e19.pdf > at 1 .

54. Ibid at 2.

55. In UNHCR's view, it "fed directly" into that forum: Riera, supra note 43 at 5.

56. Jonas Gahr Støre (Minister of Foreign Affairs, Norway) and Erik Solheim (Minister of the Environment and International Development, Norway), "A Double Predicament," in Nansen Conference: Climate Change and Displacement in the 21st Century, supra note 31 at 4.

57. Margareta Wahlström, "A Common Understanding." in Nansen Conference: Climate Change and Displacement in the 21st Century, supra note 31 at 4.

58. Jonas Gahr Støre (Minister of Foreign Affairs, Norway), "Opening Address" (6 June 2011), online: <http://d2530919 .hosted213.servetheworld.no/expose/global/download .asp?id=2222\&fk $=1581 \&$ thumb $=>$ at 2 .
59. António Guterres, "Address" (6 June 2011), online: UNHCR $<$ http://www.unhcr.org/4def7ffb9.html > at 5.

60. UNHCR Executive Committee, "Summary Record of the 610th Meeting," supra note 36 at 8, para 33. Of the seven states invited to the Bellagio expert meeting, Norway and Germany were the only developed and "non-affected" states present, on account of their keen engagement with the issue. The other states were Bangladesh, Ethiopia, Kenya, Kiribati, and the Philippines.

61. Nansen Conference, "Climate Change and Displacement in the 21st Century," background paper (6-7 June 2011), online: Norwegian Government <http://www.regjeringen .no/upload/UD/Vedlegg/Humanitært\%20arbeid/Nansen_ Conference_Background_paper.pdf $>$.

62. "Chairperson's Summary," supra note 31 at 18, para 1. See also Nansen Conference, supra note 61; Støre and Solheim, supra note 56 at 18.

63. "Chairperson's Summary," supra note 31 at 18, para 1 . See also Nansen Conference, supra note 61.

64. Guterres, supra note 59 at 4.

65. Ibid at 5 .

66. Ibid.

67. UNHCR, "Summary of Deliberations on Climate Change and Displacement," supra note 53 at 1-2.

68. Nansen Principles, Principles II, V, VI.

69. Nansen Principles, Principle IX.

70. Compared to earlier drafts, notable additions were the inclusion of environmental factors as well as climate change; the recognition of the role of actors beyond UNHCR; and the importance of using existing international law frameworks to the extent possible. One notable omission, despite a number of suggestions to include it, was the failure to reference responses to slow-onset impacts. The only tacit acknowledgement of this was a reference to "planned relocation" in Principle X.

71. Guterres, supra note 59.

72. Agnès Hurwitz, "Norm-Making in International Refugee Law" (2012) 106 Proceedings of the Annual Meeting (Am. Soc. Int'l L.) 430 at 431.

73. UNHCR Executive Committee, "Report of the 51st Meeting of the Standing Committee," supra note 36 at 7-8, paras 30-36. See generally UNHCR Executive Committee, "UNHCR's Role in Support of an Enhanced Humanitarian Response for the Protection of Persons Affected by Natural Disasters" (6 June 2011), UN Doc EC/62/SC/CRP.19 at para 4 and sources cited there: UNHCR Executive Committee, "Questions and Answers on UNHCR's Protection Cluster Coordination Role in Natural Disasters" (23 February 2011), UN Doc EC/62/SC/INF./1; Bryan Deschamp, Michelle Azorbo, and Sebastian Lohse, "Earth, Wind and Fire: A Review of UNHCR's Role in Recent Natural Disasters" (June 2010), UNHCR Policy Development and Evaluation Service, PDES/2010/06. There had been some discussion of this during 2010: see e.g. UNHCR Executive Committee, "Report of the 47th Meeting of the Standing 
Committee (2-4 March 2010)" (29 June 2010), UN Doc A/AC.96/1084; UNHCR Executive Committee, "Report of the 48th Meeting of the Standing Committee (22-24 June 2010)" (21 September 2010), UN Doc A/AC.96/1092.

74. UNHCR Executive Committee, "UNHCR's Role in Support of an Enhanced Humanitarian Response," supra note 73 at paras 2-3.

75. UNHCR Executive Committee, "Report of the 51st Meeting of the Standing Committee," supra note 36 at 7, para 33; UNHCR Executive Committee, "UNHCR's Role in Support of an Enhanced Humanitarian Response," supra note 73 at para 4.

76. UNHCR Executive Committee, "UNHCR's Role in Support of an Enhanced Humanitarian Response," supra note 73 at para 9. It had supported protection responses in natural disasters on a further four occasions. In 2010, “[m]any delegations welcomed UNHCR's willingness to undertake responsibility for persons displaced as a result of natural disasters under certain conditions-where no clear alternative leadership was present and where the affected State requested assistance": UNHCR Executive Committee, "Report of the 61st Session of the Executive Committee," supra note 36 at 16 , para 7.

77. UNHCR Executive Committee, "Questions and Answers," supra note 73 at para 22 .

78. See e.g. ibid at paras 4, 7-9.

79. For evidence of states' concerns, see UNHCR Standing Committee and Executive Committee records, supra note 36. See also the exchange in 2009 between Bangladesh and the High Commissioner about UNHCR's role in natural disasters and climate change, in which the former said it would not support an enhanced role for UNHCR and the latter said UNHCR did not want a "climate change mandate": UNHCR Executive Committee, "Summary Record of the 631st Meeting" (29 September 2009), UN Doc A / AC.96/SR.631 at 4, para 16, and at 8, para 39.

80. UNHCR Executive Committee, "Report of the 51st Meeting of the Standing Committee," supra note 36 at 4, para 8.

81. The documentary record also reveals that delegations continued to take the floor even after initial responses from UNHCR and OCHA to their concerns: see ibid at 7-8, para 34.

82. Ibid at para 31 .

83. Ibid at para 32. While the report does not reveal the views of particular states, some evidence of viewpoints can be gleaned from the summary records of Executive Committee meetings: UNHCR Executive Committee, "Summary Record of the 610th Meeting," supra note 36 at 8, para 33 (Norway), 13, para 54 (Chile), 14, para 62 (Austria); "Summary Record of the 618th Meeting" (6 October 2008), UN Doc A/AC.96/SR.618 at 11, para 53 (Switzerland); "Summary Record of the 629th Meeting" (28 September 2009), UN Doc A/AC.96/SR.629 at 2, para 1 (France), 6, para 30 (Denmark); "Summary Record of the 631st Meeting," supra note 79 at 4, para 16 (Bangladesh); "Summary
Record of the 633rd Meeting" (30 September 2009), UN Doc A/AC.96/SR.633 at 9, para 45 (Australia), 10, 51 (Netherlands).

84. UNHCR Executive Committee, "Report of the 51st Meeting of the Standing Committee," supra note 36 at para 33; UNHCR Executive Committee, "UNHCR's Role in Support of an Enhanced Humanitarian Response," supra note 73 at para 7.

85. UNHCR Executive Committee, "Report of the 51st Meeting," supra note 36 at 7 , para 32.

86. Guterres, supra note 40 at 2 .

87. Ibid at 3 . He did note, however, that climate change is not an independent variable but rather interacts with and reinforces "other global imbalances."

88. Ibid at 5-6.

89. See UNHCR, "Landmark Geneva Conference Opens with Appeal for the World's Forcibly Displaced, Stateless" (7 December 2011), online: UNHCR <http://www. unhcr.se/fi/keitae-autamme/kansalaisuudettomat/artikel/ 4b6fc167b0bbd245b0039340c49f33d6/landmark-genevaconference-opens-wit.html>.

90. António Guterres, "Address" (statement by UN High Commissioner for Refugees, delivered at the Intergovernmental Meeting at Ministerial Level to mark the 60th Anniversary of the 1951 Convention relating to the Status of Refugees and the 50th Anniversary of the 1961 Convention on the Reduction of Statelessness, Geneva, 7 December 2011), in UNHCR, Pledges 2011: Ministerial Intergovernmental Event on Refugees and Stateless Persons (Geneva, Palais des Nations, 7-8 December 2011) (Geneva: UNHCR, 2012) at 141.

91. Ibid.

92. Ibid.

93. UNHCR, supra note 8 at 4.

94. Ibid.

95. Costa Rica pledged its support after the meeting, as in his closing remarks, the High Commissioner referred to only four states: António Guterres, "Closing Remarks by the UN High Commissioner for Refugees (8 December 2011)," delivered at the UNHCR Intergovernmental Meeting at Ministerial Level to Mark the 60th Anniversary of the 1951 Convention relating to the Status of Refugees and the 50th Anniversary of the 1961 Convention on the Reduction of Statelessness, Geneva, online: UNHCR <http://www.unhcr .org/4ef094a89.html> at 1.

96. UNHCR, Pledges 2011, supra note 90 at 38; see also 76 (Germany), 96 (Mexico), 102 (Norway), 119 (Switzerland).

97. Ibid at 76 .

98. Ibid at 89.

99. Ibid at 47, referring to Migration Law No 25.871, art 24, sub-para h.

100. Ibid at 63.

101. Ibid at 58 .

102. "[W]e wish to see progress in the area of accessions to the principal refugee and statelessness conventions, 
introduction of legislative safeguards for the prevention and reduction of statelessness, and new approaches to deal with those displaced within or across national boundaries owing to environmental factors and natural disasters linked to climate change": Inter-Parliamentary Union Statement on Parliamentary Action in Support of the United Nations High Commissioner for Refugees (UNHCR) and Refugee Protection (Panama, 20 April 2011), IPU Governing Council, 188th Session, in ibid at 170-71.

103. UNHCR, Intergovernmental Event at the Ministerial Level of Member States of the United Nations on the Occasion of the 60th Anniversary of the 1951 Convention relating to the Status of Refugees and the 50th Anniversary of the 1961 Convention on the Reduction of Statelessness (7-8 December 2011), Ministerial Communiqué, UN Doc HCR/MINCOMMS/2011/6 (8 December 2011) at para 10.

104. Kälin, supra note 28 at 49.

105 The Nansen Initiative, "A Protection Agenda for DisasterInduced Cross-Border Displacement: Concept Note" (2 October 2012) at 7.

106. Guiding Principles on Internal Displacement, UN Doc E/ CN.4/1998/53/Add.2 (11 February 1998).

107 The Nansen Initiative, "A Protection Agenda," supra note 105 at 8 .

108. Ibid at $2-3$.

109. Ibid at 4 (emphasis removed).

110. Ibid at 1-3; The Nansen Initiative, "Towards a Protection Agenda," supra note 32 at 1.

111 The Nansen Initiative, "Towards a Protection Agenda," supra note 32 at 2.

112. Ibid at 2.

113 The Nansen Initiative, "Concept Note," supra note 105 at 8.

114. Ibid at 5; The Nansen Initiative, "Towards a Protection Agenda," supra note 32 at 2.

115. The Nansen Initiative, "Towards a Protection Agenda," supra note 32 at 2.

116. Nansen Initiative, Minutes of the Nansen Initiative Consultative Committee Meeting, supra note 11 at 3.

117. Steffen Kongstad (Norwegian ambassador to the UN Office at Geneva), Minutes of the Launch of the Nansen Initiative, supra note 16 at 3.

118. Ibid at 6.

119. The Nansen Initiative, "Concept Note," supra note 105 at 9. 120. Ibid.

121. José Riera (UNHCR), Minutes of the Nansen Initiative Consultative Committee Meeting, supra note 11 at 4.

122. See Minutes of the Launch of the Nansen Initiative, supra note 16 at 6 (France), 7 (US).

123. Ibid at 4 (Costa Rica), 5 (The Philippines), 7 (US).

124. Ibid at 8 (Walter Kälin).

125. Kälin, supra note 28 at 49.

126. The Initiative notes that nothing in its description of "disaster-induced cross-border displacement" should be taken to imply a direct and exclusive causality: The Nansen Initiative, "Towards a Protection Agenda," supra note 32 at 2;
Minutes of the Nansen Initiative Consultative Committee Meeting, supra note 11 at 2 . The Nansen Initiative Concept Note, supra note 105 at 6 explains, "The Initiative does not limit its purview to climate-related disasters, but addresses natural disasters regardless of the cause including geophysical hazards such as earthquakes, tsunamis or volcano eruptions. Reference to climate change is not restrictive but provides an important link to Article 14 (f) of the Cancún outcome." On complex causality, see McAdam, supra note 27 at 15-38, 196-97, and references cited therein.

127. Kälin, supra note 28 at 49.

128. "Chairperson's Summary," supra note 31 at 18, para 5.

129. UN International Strategy for Disaster Reduction, 2009 UNISDR Terminology on Disaster Risk Reduction (Geneva: UNISDR, 2009) at 9; The Nansen Initiative, "Towards a Protection Agenda," supra note 32 at 2.

130. The Nansen Initiative, "Towards a Protection Agenda," supra note 32 at 2 . This is broader than the Nansen Conference, which focused on sudden-onset disasters.

131. The Nansen Initiative, "Concept Note," supra note 105 at 7. 132. Ibid.

133. Ibid.

134. Elizabeth Ferris, "Humanitarian Perspectives on 'Protection of Persons in the Event of Disasters"' (speech delivered at the "Canada and International Law" Roundtable, Department of Foreign Affairs and International Trade, 21 April 2009), online: Brookings Institution <http://www .brookings.edu/speeches/2009/0421_natural_disasters_ ferris.aspx $>$.

135 The Nansen Initiative, “Concept Note," supra note 105 at 7.

136. This terminology was used by Jan Egeland in discussions at the Nansen Conference.

137. Nansen Initiative, “Concept Note," supra note 105 at 4, referring to Walter Kälin and Nina Schrepfer, Protecting People Crossing Borders in the Context of Climate Change: Normative Gaps and Possible Approaches (February 2012), UNHCR Legal and Protection Policy Research Series, online: UNHCR <http://www.unhcr.org/4f33f1729.pdf> at 62.

138. For a detailed overview of the Pacific sub-regional consultation, see Jane McAdam, "Creating New Norms? The Nansen Initiative on Disaster-Induced Cross-Border Displacement" (1 April 2013), online: Asia-Pacific Migration and En vironment Network, http://apmen.iom.int/en/m/editorials/ item/104-creating-new-norms-the-nansen-initiative-on -disaster-induced-cross-border-displacement>.

139. "Message from the Prime Minister of the Cook Islands," in Nansen Initiative, 4.

140. See Jane McAdam, "Swimming against the Tide: Why a Climate Change Displacement Treaty Is Not the Answer" (2011) 23 Int'l J. Ref. L. 1, and the critique of treaty proposals there.

141. "Review of the Use of UNHCR Executive Committee Conclusions on International Protection" (9 June 2008), online: UNHCR < http://www.unhcr.org/483d701f2.html> at 8 . 
142. Kälin and Schrepfer, supra note 137 at 71.

Jane McAdam is a Scientia Professor of Law and Australian Research Council Future Fellow at the University of New South Wales, Australia. She is also the Director of the Andrew \& Renata Kaldor Centre for International Refugee Law at UNSW and a Non-resident Senior Fellow at Brookings. The authormay be contacted at j.mcadam@unsw.edu.au. are credited and the original publication in Refuge: Canada's Journal on Refugees is cited. 